PART 1

Higher Education and Civic Space for Learning 
Ana Maria de Albuquerque Moreira, Andrea Tejera Techera, Márcia Lopes Reis, and Sebastian Schurmann - 9789004459076 Downloaded from Brill.com04/26/2023 10:53: ๑3AM via free access 


\title{
The University and the Tensions of Inclusion as Part of the Ethos of Social Responsibility
}

\author{
Ana Maria de Albuquerque Moreira, Andrea Tejera Techera, \\ Márcia Lopes Reis and Sebastian Schurmann
}

\begin{abstract}
This chapter analyses the challenges for social responsibility in higher education in a scenario of growth of enrolments in three Latin American Countries: Argentina, Brazil, and Uruguay. After demonstrating the social inclusion policies in higher education in each country, the analysis is based on Bourdieu's concept of habitus.
\end{abstract}

\section{Keywords}

inclusion - social responsibility - habitus

\section{Introduction}

In this chapter, we delineate a study conducted on the theme of social responsibility as a tension in higher education institutions in three Latin American countries - Argentina, Brazil and Uruguay. Though they have different historical traditions, in the manner of structuring higher education systems, they share some common traits.

The three countries can be considered to be predominantly unequal societies by economic, social and cultural factors, which, in turn, produce educational exclusion, distancing the vulnerable collective's access to higher education for excellence (Dias Sobrinho, 2010). In general, the Latin American universities could be considered, by their conceptions of academic and professional excellence, to be associated with an intellectual elite.

The rupture of this historical way of becoming a university can be understood by the point of view of the conditions of compliance with social responsibility and the tensions in relations to social inclusion. Albeit by different logics, the three countries have been implementing practices and regulations for access 
and retention of graduates from vulnerable collectives aimed at social inclusion, based on the maturity of their national higher education systems. Due to the rupture of its exclusionary traditions, the concept of habitus (Bourdieu, 1997) represents the theoretical-methodological trajectory of this analysis.

\section{Higher Education in Argentina}

The first universities in Argentina date back to the 17th century, when, in 1622, the Jesuit College Cordobés became a university. This was followed by the creation, in 1821, of the University of Buenos Aires (Morresi et al., 2017). Normatively they are regulated by the Law on Higher Education (LES 24,521), enacted in 1995, which defines the functions of university institutions and their operating conditions, accreditation and support, among other aspects. Some of the main features of the Argentine university system are access to the majority of universities without screening tests, the gratuity of the studies in the institutions under state management (which, historically, led to the fact that a major part of tuition focuses on the most prestigious national universities), and a lack of vacancies of quotas that determine a maximum number of students to admit per course (García de Fanelli, 2014).

According to the last available data (2017), 131 university institutions in Argentina can be classified by management area (state-national, state-provincial, private or foreign/international) or by type (universities or university institutes $\left.{ }^{1}\right) .85 \%$ of the institutions are universities, the vast majority of which are either national or private management (Table 1.1). It should also be noted that, until 1989, there were 51 university institutions, and the expansion of the

TABLE 1.1 Number of universities by type and management area. Argentina, 2017

\begin{tabular}{lrrr}
$\begin{array}{l}\text { Management } \\
\text { area }\end{array}$ & \multicolumn{2}{c}{ Type } & Total \\
\cline { 2 - 4 } & Universities & University institutes & \\
\hline State national & 57 & 4 & 61 \\
State provincial & 4 & 1 & 5 \\
Private & 49 & 14 & 63 \\
Foreign/ international & 1 & 1 & 2 \\
Total & $\mathbf{1 1}$ & $\mathbf{2 0}$ & $\mathbf{1 3 1}$ \\
\end{tabular}


system was mainly in two periods: between 1989 and 1999, with the creation of 35 institutions, 23 of which were from private management; and between 2007 and 2015, with the creation of 33 institutions, 24 of which were state national management (19) and provincial (5) (Chiroleu, 2018).

Considering the population, the Argentine university system brings together $2,164,500$ students, of which $93 \%$ are undergraduate students, and about $80 \%$ are in state-run institutions (national or provincial). The number of registered students represents a net enrollment rate of $19.7 \%$ for the population of young people aged 18 to 24 years old (DIU, 2019).

In the last 10 years, the population of undergraduate students has risen steadily at an average rate of $2.8 \%$ per year, from 1,569,063 in 2007 to 2,005,152 in 2017. New registrants increased annually at a rate of $4.2 \%$, from 362,735 in 2007 to 516,305 in 2017 , and graduate students at a rate of $4.5 \%$, from 86,528 to 125,328 in the same period.

One of the main policies of inclusion in the Argentine university system has been the territorial expansion of offerings and the sustained increase in enrollment, along with some scholarship and tutoring programmes for courses. However, as García de Fanelli (2014, p. 290) points out, levels of abandonment are high, particularly for young people from lower-income socioeconomic sectors, given that "[higher education] is associated with the cultural capital of the family and with the possibilities of young people having access to quality high school education".

Higher education in Brazil began late, compared to other Latin American countries. The establishment of the first university, the University of Brazil, dates back to 1920. The historical evolution of the national system of higher education was marked by the structuring inequalities in Brazil's economic, social and cultural formation, which were decisive in the complexity and heterogeneity of institutions and in the inequality of the students who accessed that level of schooling.

The first distinction is in the administrative category, or management area, of higher education institutions: public or private. Public institutions (federal, state or municipal) belong to the state, and registrations to it are free of charge, as determined in the Federal Constitution of 1988, while private institutions may be for-profit or non-profit (or even denominational). In the period from 2000 to 2018 , the number of private institutions grew by $123 \%$, from 1,004 to 2,238 institutions, whereas the number of public/state institutions grew by 
TABLE 1.2 Number of institutions by type and management area. Brazil, 2018

\begin{tabular}{|c|c|c|c|c|c|}
\hline \multirow{2}{*}{$\begin{array}{l}\text { Management } \\
\text { area }\end{array}$} & \multicolumn{4}{|c|}{ Type } & \multirow[t]{2}{*}{ Total } \\
\hline & University & University centre & Faculty & Federal institute & \\
\hline Public & 107 & 13 & 139 & 40 & 299 \\
\hline Private & 92 & 217 & 1.929 & n.a. & 2.238 \\
\hline Total & 199 & 230 & 2.068 & 40 & 2.537 \\
\hline
\end{tabular}

SOURCE: HIGHER EDUCATION CENSUS, INEP/MEC

$70 \%$, from 176 to 299 institutions, most of them universities. In Brazil, HE Is can be of different academic types, including universities, university centres, faculties or federal institutes ${ }^{2}$ (Table 1.2).

The Brazilian higher education system brings together a large number of students. Between 2008 and 2018, enrolment in graduation courses increased by $44.6 \%$, from $5,843,322$ to $8,451,748$ students; the percentage of new entrants rose by $47.4 \%$, from $2,336,899$ to $3,445,935$, and the number og graduate students grew by $45 \%$, from 870,386 to $1,264,288$. There is a higher concentration of enrollments in private institutions - in $2018,75 \%$ of the enrollments were in private institutions.

Between 2000 and 2018, the number of students in postgraduate courses increased by more than $200 \%$, rising from 117,595 , in 2000 , to 375,923 in 2018 (Geocapes/Capes). Despite this expressive expansion, only o.8\% of the population aged 25 to 64 years old had completed a master's degree in Brazil (OECD, 2019). And, in opposition to the undergraduate courses, the majority of which are offered by private institutions, postgraduate course offerings are concentrated in public/state institutions (80\%).

The growth in the number of students by itself does not mean equity. So, in order to change the exclusion scenario, access to universities has to be democratised and support has to be lent to vulnerable students in higher education. Supportive policies in the private sector include financing strategies for undergraduate courses, such as the Student Financing Aid (FIES), a refundable programme and the University for All programme (PROUNI), a non-refundable programme. In the public sector, national policies have focussed on ensuring greater equity through the National Student Assistance Program (PNAES) and the Quota $\mathrm{Law}^{3}$ (Law 12,711, 2012). There are also inclusion policies at the level of states and HEIs.

The implementation of inclusive policies has had important effects on the students' profile at the public and private HEIs, especially in the inclusion of those 
students from vulnerable collectives. The quota programme is responsible for including vulnerable collectives in higher education, by different characteristicis: social/family income, disability, ethnic/racial background and public secondary education.

Despite these important changes, other data show the challenges to reduce inequalities that exist in the Brazilian higher education system. In 2017, the net fequency rate (that is, school attendance rate at an appropriate age and level of education) for $18-24$ years was $23.2 \%$; with that of whites $(32.9 \%)$ being twice that of blacks $(16.7 \%)$. Based on average income per capita, there is a significant difference between the poorest quintile $(6 \%)$ and the richest quintile (58\%) (IBGE, 2018).

In Uruguay, university education started with the establishment of the University of the Republic (UdelaR), a public institution, in 1833 . Today, the educational system is generally regulated by the Constitution of the Eastern Republic of Uruguay (1968) and by the General Education Law (Law 18,437, 2008). From an institutional point of view, the Ministry of Education and Culture (MEC) has a regulatory role, and the general coordinator for the design and implementation of educational policies depends on autonomous entities.

According to the General Education Law, tertiary education (also called higher education) is divided into three categories: tertiary non-university education, training in education and university education. Although this standard foresees the creation of the University Institute of Education, it has not yet been implemented. In all three cases, we can find public and private institutions (Table 1.3).

TABLE 1.3 Number of institutions by type and amangement area. Uruguay, 2019

\begin{tabular}{lccccc}
\hline $\begin{array}{l}\text { Mangement } \\
\text { area }\end{array}$ & \multicolumn{3}{c}{ Type } & Total \\
\cline { 2 - 5 } & Universities & $\begin{array}{l}\text { Education } \\
\text { training }\end{array}$ & $\begin{array}{l}\text { University } \\
\text { education }\end{array}$ & $\begin{array}{l}\text { Tertiary non-university } \\
\text { education }\end{array}$ \\
\hline $\begin{array}{l}\text { Public } \\
\text { Private }\end{array}$ & 2 & 33 & & 4 & 35 \\
Total & 5 & & 12 & 4 & 21 \\
& 7 & 33 & 12 & 56
\end{tabular}

SOURCE: MEC (2019) 
The focus of this study is in university education (training in production and reproduction of knowledge) and education training (teacher training, technical teachers, teachers, physical education teachers, and social educators).

Training in education, in 2018, had 27,468 students enrolled, covering both public institutions as well as private centres and institutes (MEC, 2018).

In the case of universities, enrolment in 2018 was 107,623 , of which 85,905 students were at the University of the Republic, 1,107 at the Technological University and 20,611 atprivate universities. Although the student enrolment has shown a fairly constant growth rate in recent years, compared to 2017 there was a decrease by 1,194 students (MEC, 2018).

With regards to university education and the relationship between income and expenses, there has been a steady growth in income until 2011, after which there is a decline and then it remains constant. Expenditures, however, have continued to increase throughout the period, tripling between 2007 and 2017.

Uruguay has different programmes and initiatives that seek to impact the educational system, higher education in particular, with regards to ensuring greater and better access, permanence and discharge of students, since the amount of income, in the case of the UdelaR, is notoriously higher than the expenses. It should be clarified that the increase in enrollment does not always show the positive functioning of these programmes, but may also show the 'lag' that occurs as a result of the increase in repetition rates. Another important element to consider when looking at enrolment rates is that, in Uruguay, the system admits multiple enrollments; therefore, the numbers we are looking at do not correspond exactly to the number of students.

One supportive measure adopted by universities is the granting of scholarships (economic assistance, transportation, food, and residence). Within these grants, the most comprehensive initiative is the Solidarity Fund of UdelaR, which supports the continuity of students, with a criterion of territorial equity, since most of the scholarships are given to students from counties or rural areas. Further, a higher percentage of women receive such scholarships. In 2017, 8,238 students benefited from such grants (MEC, 2017).

Another supportive mechanism is the Central University Welfare Service in UdelaR, with benefits for students from lower socioeconomic backgrounds. In 2017, this service delivered 4,325 financial support grants (MEC, 2017). For education training, the Education Training Council (CFE) supports students for the completion of their programmes, granting, in 2017, a total of 2,197 scholarships (MEC, 2017).

There are other scholarships and support programmes with less coverage than those referenced before. The Educational Scholarship Panorama Report (MEC, 2019) shows that the granting of scholarships has increased sixfold in the period from 2005 to 2018 . 
Likewise, the country has a specific regulation that supports public policies in human rights and inclusion and for its implementation, has generated institutionality of different order (RedAGE, 2017).

\section{5}

\section{Social Inclusion as Part of the Ethos of Social Responsibility}

At the beginning of this second decade of the 21st century, the challenges seem to be the fulfillment of a social function that encompasses minorities and fosters the reduction of structural inequities. In this sense, for universities to fulfill their social responsibility - a concept that has developed from the business method of evaluating institutional practices - they seem to need actions at the micro-sociological level of the organisational culture of these institutions and at the intermediate level of the regions and also at a federal level.

This social inclusion process, due to its underlying tensions, causes changes in the habitus that can be seen in actions common to the three countries, especially in policies, programmes, and projects that result in a change beyond the expansion of higher education systems, over the last four decades. These advances require other characteristics, such as massification of the education system, inclusion of historically excluded groups, development of research centres, creation of activities shared with the private sector, innovation in teaching and learning processes through the mediation of technologies, contribution of international cooperation programmes and its networks of good practices, and lifelong learning.

Following these similarities, the analyses seem very suitable to be understood from the concept of habitus (Bourdieu, 1997), because one of the functions of that concept is to account for the unity of style that unites the practices and goods of a single agent or a class of agents. Thus, if the habitus is the one generating and unifying principle that retransmits a unitary set of choices on people, goods and practices, it seems relevant that the analyses to be proposed are made from there: systematised forms of regulation of everyone's access to the university, data under the theme of the permanence and success of the expenses, including other features of a social responsibility carried out in their daily ways of doing. Because of their cultural differences, the three countries implement different practices for monitoring the groups that have accessed the university from these new forms of social responsibility.

As Schwartzman (2014) has observed, this happens because universities remain involved in their daily problems and present great difficulties in learning with the transformations that keep happening. Higher education systems in Argentina, Brazil and Uruguay seem to have new tensions between the new way of being and analysing historical and excluding practices. 
Despite the inequities that still exist, the three countries have been making efforts to enable social inclusion in higher education. Since the inclusion of vulnerable collectives, the universities have changed in various aspects that take part in the habitus (Bourdieu, 2007): regulations, policies, and practices of universities in their actions toward the inclusion of nontraditional students in higher education.

In this scenario, the universities in Argentina, Brazil, and Uruguay are encouraged to think about their role in society, beyond their traditional functions of teaching, research and extension. The challenges for social responsibility for universities (Ribeiro \& Magalhães, 2014; Sobrinho, 2018) in common contexts of inequality become stronger, intending to generate ethical and sustainable policies that have an impact on society to contribute to equitable development.

\section{Notes}

1 In Argentina, those university institutions that circumscribe their academic offer to a single disciplinary area are qualified as "university institutes" (CONEAU, n.d.).

2 In Brazil, universities offer teaching, research, and extension programs. University centres fulfill mainly teaching, and other activities are not mandatory; both types of institutions have academic autonomy. Faculties offer education and have no autonomy. In the private sector, most institutions are faculties, which are generally low cost. Federal institutes and federal centres for technological education are public institutions, maintained by the federal government and intended for technical and technological training. However, they also offer secondary education and postgraduate courses (Carvalho \& Moreira, 2018).

3 The Quota Law establishes $50 \%$ of vacancies in undergraduate courses in public institutions, according to the following criteria: race/colour (black students); family income (lower) and type of secondary school (public).

\section{References}

Bourdieu, P. (1997). Razões práticas: sobre a teoria da ação. Papirus.

Bourdieu, P. (2007). El sentido práctico. Siglo XXI Editores.

Carvalho, C. H. A., \& Moreira, A. M. A. (2018, December 5-7). Public policies for reducing inequalities in Federal Brazilian higher education: Main findings. Paper presented at Society for Research into Higher Education Annual Conference: The changing shape of higher education - Can excellence and inclusion cohabit?

Chiroleu, A. (2018). Democratización e inclusión en la universidad argentina: sus alcances durante los gobiernos Kirchner (2003-2015). Educação em Revista, 34, e176oo3. 
Comisión Nacional de Evaluación y Acreditación Universitaria (CONEAU). (n.d.). Institutos Universitarios (documento electrónico). Retrieved February 8, 2020, from http://www.coneau.gob.ar/archivos/49o.pdf

Dias Sobrinho, J. (2010). Democratização, qualidade e crise da educação superior: faces da exclusão e limites da inclusão. Educação e Sociedade, Campinas, 31(113), 1223-1245.

Dias Sobrinho, J. (2018). Responsabilidade social da Universidade em questão. Avaliação, Campinas; Sorocaba, SP, 23(०3), 586-589.

DIU. (2019). Departamento de Información Universitaria. Síntesis de información de estadísticas universitarias 2017-2018. Ministerio de Educación, Cultura, Ciencia y Tecnología. Retrieved February 8, 2020, from https://www.argentina.gob.ar/sites/ default/files/sintesis_2017_-_2018.pdf

García de Fanelli, A. (2014). Inclusión social en la Educación superior Argentina: Indicadores y políticas en torno al acceso y a la graduación. Páginas de Educación, Revista de la Facultad de Ciencias Humanas, 7, 275-297.

Geocapes/Capes. (n.d.). Sistema de Informações Georreferencidas/Capes. https://geocapes.capes.gov.br/geocapes/

IBGE. (2018). Instituto Brasileiro de Geografia e Estatística. Síntese de indicadores sociais uma análise das condições de vida da população brasileira. Coordenação de População e Indicadores Sociais. Author.

INEP. (2018). Instituto Nacional de Estudos e Pesquisas Educacionais Anísio Teixeira. Sinopse Estatística da Educação Superior 2018. Retrieved February 5, 2020, from http://portal.inep.gov.br/basica-censo-escolar-sinopse-sinopse

MEC. (2008). Minsiterio de Educación y Cultura. Ley General de Educación No 18437. Artes Gráficas.

MEC. (2017). Minsiterio de Educación y Cultura. Panorama de la Educación. Uruguay.

MEC. (2018). Minsiterio de Educación y Cultura. Anuario estadístico de educación. Uruguay.

MEC. (2019). Minsiterio de Educación y Cultura. Panorama de becas educativas 2018. Uruguay.

Ministério de Educación. Secretaria de Políticas Universitárias. (2020). Sistema de consulta de estadísticas universitárias. Retrieved February 8, 2020, from http://estadisticasuniversitarias.me.gov.ar/

Morresi, S., Ibáñez Martín, M., \& Arnaudo, M. F. (2017, November 6-8). Inclusión educativa: ¿Las nuevas Universidades Nacionales colaboran en el proceso inclusivo? VI Congreso Nacional y Internacional de Estudios Comparados em Educación: Inclusión, Calidad y Equidad en la Educación. Pasado, Presente y Futuro en perspectiva comparada. Buenos Aires, Argentina. http://www.saece.com.ar/docs/congreso6/ trabo79.pdf

OECD. (2019). Education at a glance 2019: OECD indicators. Author. https://doi.org/10.1787/f8d788od-en 
Pedrosa, R. H. L. (2013). A universidade e a inclusão social. Revista Latinoamericana de Psicopatologia Fundamental, 16(1), 13-16. https://dx.doi.org/10.159o/S141547142013000100001

RedAGE. (2017). Tendencias en políticas educativas sobre derechos humanos e inclusión en Uruguay. Serie Informes 9 (Chapter 12, pp. 210-230). https://ddd.uab.cat/ pub/llibres/2017/188838/Libro_Red_AGE_2018.pdf

Ribeiro, R. C., \& Magalhães, A. M. (2014). Política de Responsabilidade Social na Universidade: Conceitos e desafios. Educação, Sociedade \& Cultura, 42, 133-156.

Schwartzman, S. (Ed.). (2014). A educação superior na América Latina e os desafios do século XXI. Ed. Unicamp.

Silveira, L. C. T. (2018). Widening access to higher education for low-income students: A Brazilian case study (1990s-2016). Revista Brasileira de Educação, 23, e230023. https://dx.doi.org/10.159o/s1413-24782018230023 